\title{
Applicability of Lindera obtusiloba Flower Extracts as Cosmetic Ingredients
}

HyeonAh Yu, Chun Dug Kim*

Department of Cosmetology Science, Nambu University, Gwangju, Korea

\author{
*Corresponding author: Chun Dug Kim, \\ Department of Cosmetology Science, \\ Nambu University, 23 advanced Jungang-ro, \\ Gwangsan-gu, Gwangju 62271, Korea \\ Tel.: +82 629700139 \\ Fax: +82 629700139 \\ Email: chun@nambu.ac.kr
}

Received September 22, 2016

Revised March 13, 2017

Accepted March 26, 2017

Published June 30, 2017

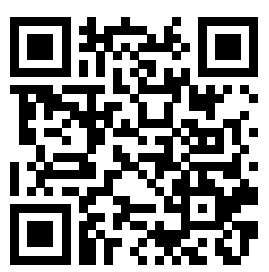

\begin{abstract}
Purpose: This study confirms the cosmeceutical effects of the Lindera obtusiloba ( $L$. obtusiloba) flower and its applicability as a natural cosmetic ingredient. Methods: After obtaining the extracts from the L. obtusiloba flower using hot water and $70 \%$ ethanol, its anti-oxidation, whitening, wrinkle improvement, and anti-bacterial properties were measured. Results: The ethanol extracts from the L. obtusiloba flower had a 2,2-diphenyl-1-picrylhydrazyl (DPPH) radical scavenging effects of $81.33 \%$ at $500 \mu \mathrm{g} / \mathrm{mL}$ and contained phenol and flavonoid concentrations of 152.00 and $145.27 \mu \mathrm{g} / \mathrm{mL}$, respectively, which were higher than those seen in the hot water extracts. With respect to the whitening effects of the L. obtusiloba flower, the ethanol extracts suppressed tyrosinase enzyme activity by $31.00 \%$ at a concentration of $500 \mu \mathrm{g} / \mathrm{mL}$. In B16F10 melanoma cells, the extracts showed excellent inhibitory effects on tyrosinase and melanin biosynthesis. Its inhibitory effects on $\alpha$-melanocyte-stimulating hormone ( $\alpha-\mathrm{MSH}$ )-induced tyrosinase activity and melanin biosynthesis were higher than those observed using the positive control, arbutin. The measurement of procollagen synthesis confirmed the wrinkle improvement effects of the $L$. obtusiloba flower, with the ethanol extracts promoting a $130.00 \%$ increase in procollagen biosynthesis. The anti-bacterial effects of the L. obtusiloba flower extracts on Staphylococcus epidermidis (S. epidermidis), Staphylococcus aureus (S. aureus), and Propionibacterium acnes (P. acnes) were assessed. Here the ethanol extracts had the greatest anti-bacterial effects on $S$. epidermidis and $P$. acnes. Conclusion: $L$. obtusiloba flower extracts are expected to be highly applicable as natural functional cosmetics of material having skin whitening, wrinkle improvement, and anti-bacterial effects.
\end{abstract}

Keywords: Lindera obtusiloba, Anti-oxidation, Whitening, Anti-bacterial effects, Cosmetics

\section{Introduction}

현대 사회에서 외모는 사회적 경쟁력 중 하나라는 인식이 증가 하고 있으며 의학적, 생활적 수준이 향상됨에 따라 인간의 평균 수 명이 증가하면서 건강한 삶과 아름다움에 대한 욕구가 강해지고 있 다. 이러한 시대적 변화와 관심의 증가를 바탕으로 화장품 분야의 시장 규모가 확대되었고, 이와 관련된 연구가 다각도로 진행되고 있다(Han et al., 2014; Joo et al., 2015).

피부는 전신을 둘러싸며 외부로부터 여러 가지 자극 및 장해, 혹은 건조로부터 생체를 보호하는 역할을 하고 있다(Jeon et al., 2014). 오늘날 사람들은 사회활동의 증가뿐만 아니라 환경오염에
따른 오존층 파괴로 유해 자외선에 장기적으로 노출되어, 멜라닌 침착 과다 현상으로 인한 피부 흑화, 색소 침착, 피부암 등 피부 건강뿐만 아니라 미적 측면에서도 크게 영향을 받고 있다(Hwang et al., 2013).

멜라닌은 사람의 눈동자, 머리카락, 피부색 등을 결정하는 중요 한 요인으로, 자외선과 외부환경으로부터 피부 내부를 보호할 목 적으로 생성되나, 과도하게 생성되는 경우 멜라닌이 피부에 침착 되어 기미, 주근깨, 검은 반점 등의 피부질환을 일으킨다(Kim et al., 2015). 따라서 멜라닌의 생성을 억제하거나 생성된 멜라닌을 제거하는 방법으로 미백화장품의 설계가 이루어지고 있다. 멜라닌 은 표피의 기저층의 melanocyte로부터 합성되며, 멜라닌의 생합 
성 과정에 작용하는 주요효소는 tyrosinase로, polyphenol oxidase 의 일종이며 구리를 함유한 효소로서 색소 세포에서 tyrosine을 3,4-dihydroxy-L-phenylalanine (L-DOPA)로 변환시키고 효 소적 산화반응에 의해 dopaquinone, dopachrome으로 산화하여 멜라닌을 생합성한다.

따라서 산화적 반응을 매개하는 tyrosinase의 활성을 억제함으 로써 멜라닌의 합성을 저해시켜 미백 효과를 나타내는 물질을 스 크리닝하는 연구가 활발하게 이루어지고 있다(Kim et al., 2013). 현재 kojic acid, arbutin, ascorbic acid, retinoic acid, catechin, aloesin, resveratrol 등이 미백에 효과적인 성분임이 보고되어 식 품산업을 비롯한 화장품과 의학 분야에서도 널리 상업적으로 이 용되고 있지만 피부의 알러지를 유발하거나 독성을 나타내어 사 용이 매우 제한적이다(Jang et al., 2015; Yoo et al., 2013).

생강나무는 한국, 중국, 일본의 산간지에 분포하는 녹나무과의 활엽소 교목으로, 높이는 $3 \mathrm{~m}$ 정도 자라며 수피는 검은 회색으로 벗겨 냄새를 맡으면 강한 생강냄새가 발산된다. 잎은 호생하는데 난원형 또는 넓은 난형이고 길이는 5-15 cm, 폭은 3-13 cm 정도에 서 보통 3-5개가 갈라져 있으며 앞면은 녹색이고, 뒷면은 맥에 털 이 있다. 꽃은 자웅이주로서 잎보다 먼저 노랑꽃이 피며 9 개의 수 술과 1 개의 암술이 있다. 열매는 장과로서 둥글고 직경이 7-8 mm 정도 되며, 푸른색에서 붉은색으로 변하여 9-10월에 검은색으로 익는다(Moon \& Lee, 1997).

생강나무를 이용한 국내연구는 gas chromatography mass spectrometry를 이용한 계절에 따른 생강나무의 부위별 향기 성 분 비교 분석(Hwang et al., 2005), 제조방법에 따른 생강나무 잎 차의 성분변화(Hwang et al., 2003), 제조방법에 다른 생강나무 잎차의 향기 성분의 변화(Hwang et al., 2005), 잎과 가지의 정유 성분(Kwon et al., 2007) 등이 있으며, 기능성 식품 및 화장품 소 재로서의 연구로는 식중독균에 대한 항균 활성(Kim et al., 2014), 암 전이 억제 효과(Yun et al., 2012), 항산화 효과 및 티로시나 아제 저해 활성(Won et al., 2012), 광노화에 의한 주름형성 억제 효과(Park et al., 2009), 잎 및 가지 추출물의 생리 활성(Hong, 2013), 알레르기성 염증반응 억제 효과(Kim et al., 2009), 항산화 활성과 미백 효과(Bang et al., 2008) 등이 보고되었다. 그러나 생 강나무 꽃에 관한 연구는 매우 미비한 실정이다.

따라서 본 연구에서는 생강나무 꽃을 열수 및 $70 \%$ 에탄올로 추출 하여 항산화, 미백 효능, 주름 개선 및 항균 활성 등을 측정하여 약 리 활성 검증 및 화장품 천연소재로서의 활용 가치를 검토하였다.

\section{Methods}

\section{1. 시료조제}

본 실험에 사용한 생강나무 꽃은 홍천 곰수골 농장(Korea)에서
구입하여 시료로 사용하였다. 열수 추출은 정제수 $1 \mathrm{~L}$ 에 생강나 무 꽃 $10 \mathrm{~g}$ 을 넣어 $90^{\circ} \mathrm{C}$ 에서 $24 \mathrm{~h}$ 동안 추출하였고, 에탄올 추출은 $70 \%$ 에탄올 $1 \mathrm{~L}$ 에 생강나무 꽃 $10 \mathrm{~g}$ 을 넣어 $60^{\circ} \mathrm{C}$ 에서 $24 \mathrm{~h}$ 동안 추출하였다. 추출액은 여과지(Whatman filter paper No.2; GE Healthcare Life Sciences, USA)를 사용하여 여과하였고, 감압 농축기(EYELA N-1000; Tokyo Rikakikai, Japan)를 이용하여 감압 농축한 후 동결 건조하여 냉동 보관하였다. 열수 추출물의 수 득률은 $26.8 \%$, 에탄올 추출물의 수득률은 $17.8 \%$ 로 나타났다.

\section{2. 생강나무 꽃 추출물의 항산화 활성 검색}

1) $\mathrm{DPPH}$ 라디칼 소거 활성 검색

항산화 활성 검색은 $\mathrm{DPPH}$ 법을 이용하여 시료의 라디칼 소거 효과를 측정하는 Blois (1958)의 방법을 변형하여 측정하였다. $1 \times$ $10^{-4} \mathrm{M} \mathrm{DPPH}$ 용액 $100 \mu \mathrm{L}$ 와 농도별 생강나무 꽃 추출물을 각각 $100 \mu \mathrm{L}$ 씩 취하여 혼합한 후 $30 \mathrm{~min}$ 동안 암실에서 방치한 후 잔존 라디칼 농도를 microplate reader (Molecular Devices, USA)를 이 용하여 $517 \mathrm{~nm}$ 에서 측정하였다. 시료의 환원력의 크기는 라디칼 소거 활성(radical scavenging activity)으로 표시하며, 항산화 물 질로 잘 알려진 butylated hydroxytoluene (BHT) 및 vitamin $\mathrm{C}$ 와 비교하였다.

\section{2) 총 폴리페놀 함량 측정}

총 폴리페놀 함량은 Folin \& Denis (1915) 방법을 따라, 생강나 무 꽃 추출물 $(1 \mu \mathrm{g} / \mathrm{mL}) 50 \mu \mathrm{L}$ 에 증류수 $650 \mu \mathrm{L}$ 를 넣은 후 FolinDenis reagent (Sigma-Aldrich, USA)를 $50 \mu \mathrm{L}$ 가하여 $3 \mathrm{~min}$ 동 안 실온에서 반응시킨다. 반응시킨 후 $10 \%$ calcium carbonate ( $\mathrm{Na}_{2} \mathrm{CO}_{3}$; Sigma-Aldrich) 포화용액 $100 \mu \mathrm{L}$ 을 첨가하고, 최종 부피를 $1 \mathrm{~mL}$ 로 맞추기 위해 증류수 $150 \mu \mathrm{L}$ 을 넣어 잘 혼합시켰 다. $37^{\circ} \mathrm{C}$ water bath에서 $1 \mathrm{~h}$ 반응시킨 후 microplate reader (Molecular Devices)를 이용하여 $725 \mathrm{~nm}$ 에서 흡광도를 측정하였 다. 총 폴리페놀 함량은 tannic acid (Sigma-Aldrich)를 이용하여 작성한 표준곡선을 이용하여 환산하였다.

\section{3) 총 플라보노이드 함량 측정}

총 플라보노이드 함량은 Davis 등의 방법에 따라(Swain \& Hillis, 1959), 생강나무 꽃 추출물 $(1 \mu \mathrm{g} / \mathrm{mL}) 100 \mu \mathrm{L}$ 에 $1 \mathrm{~mL}$ 의 diethylene glycol (Sigma-Aldrich)을 첨가하고 다시 $1 \mathrm{~N}$ sodium hydroxide $(\mathrm{NaOH}) 100 \mu \mathrm{L}$ 을 넣어 잘 혼합시켜 $37^{\circ} \mathrm{C}$ water bath에서 $1 \mathrm{~h}$ 동안 반응시킨 후 microplate reader (Molecular Devices)를 이용하여 $420 \mathrm{~nm}$ 에서 흡광도를 측정하였다. 총 플라 보노이드 함량은 naringin (Sigma-Aldrich)를 이용하여 작성한 표준곡선을 이용하여 환산하였다. 


\section{3. 생강나무 꽃 추출물의 미백 효과}

\section{1) Mushroom tyrosinase 저해 활성 측정}

Tyrosinase 저해 활성 측정은 Yagi et al. (1987)의 방법에 따라 측정하였다. 기질액은 $10 \mathrm{mM} \mathrm{L-DOPA} \mathrm{(Sigma-Aldrich)를} 0.175$ M sodium phosaphate buffer (pH 6.8; Sigma-Aldrich) $500 \mu \mathrm{L}$ 에 녹여 준비한 후, 기질액 $200 \mu \mathrm{L}$ 와 시료용액 $100 \mu \mathrm{L}$ 의 혼합액에 mushroom tyrosinase (110 U/mL; Sigma-Aldrich) $200 \mu \mathrm{L}$ 을 첨 가하여 $25^{\circ} \mathrm{C}$ 에서 $2 \mathrm{~min}$ 동안 반응시켜 반응 중에 생성된 L-DOPA dopaquinone을 $475 \mathrm{~nm}$ 에서 측정하였다. Tyrosinase 저해 활성은 시료용액의 첨가구와 무 첨가구의 흡광도 감소율로 나타내었다.

\section{2) 세포주 배양}

B16F10 melanoma 세포는 한국세포주은행(Korea)에서 구입 하였다. Dulbecco's Modified Eagle Medium (DMEM; Gibco ${ }^{\mathrm{TM}}$, Thermo Fisher Scientific, USA)배지에 10\% fetal bovine serum (FBS; Sigma-Aldrich)과 1\% penicillin/streptomycin $(\mathrm{P} / \mathrm{S}$; Sigma-Aldrich)을 첨가한 DMEM 배양액을 이용하여 $\mathrm{B} 16 \mathrm{~F} 10$ melanoma 세포를 $37^{\circ} \mathrm{C}, 5 \% \mathrm{CO}_{2}$ 의 습윤화된 incubator 에서 배양하였다.

\section{3) MTT assay에 의한 세포 생존율 측정}

B16F10 melanoma 세포를 24 well plate에 well 당 $1 \times 10^{5}$ cells/ well을 분주하여 $24 \mathrm{~h}$ 배양하였다. $24 \mathrm{~h}$ 의 배양이 끝난 후 생강나 무 꽃 추출물을 최종농도 10-400 $\mu \mathrm{g} / \mathrm{mL}$ 이 되게 배양액에 희석하 여 부착 및 안정화된 세포주에 공급하고 $72 \mathrm{~h}$ 동안 배양하였다. 배 양완료 후 well에 3-(4,5-dimethyl-2-thiazolyl)-2,5-diphenyl$2 \mathrm{H}$-tetrazolium bromide (MTT) $[5 \mathrm{mg} / \mathrm{mL}$ in phosphate buffered saline (PBS)] 용액을 가해주고 다시 $37^{\circ} \mathrm{C}, 5 \% \mathrm{CO}_{2}$ 의 습 윤 배양기에서 $4 \mathrm{~h}$ 동안 반응하여 MTT가 환원되도록 하였다. 각 well에 생성된 formazan 결정을 dimethyl sulfoxide $150 \mu \mathrm{L}$ 로 잘 녹여서 microplate reader (Molecular Devices)를 이용하여 $540 \mathrm{~nm}$ 에서 흡광도를 측정하였다.

\section{4) 세포에서의 tyrosinase 저해 활성 측정}

B16F10 melanoma 세포의 tyrosinase 활성은 MartínezEsparza et al. (1998) 방법을 사용하였다. B16F10 melanoma 세 포를 24 well plate에 각각 $1 \times 10^{5}$ cells/well의 농도로 분주하고 24 $\mathrm{h}$ 동안 배양한 다음, 생강나무 꽃 추출물을 $10-200 \mu \mathrm{g} / \mathrm{mL}$ 처리한 후 $72 \mathrm{~h}$ 배양하였다. $72 \mathrm{~h}$ 배양한 후 각 well를 $10 \mathrm{mM} \mathrm{PBS}$ 로 세 척하였으며, 1\% Triton X-100 (Sigma-Aldrich)을 함유한 $10 \mathrm{mM}$ PBS $100 \mu \mathrm{L}$ 에 현탁시켰다. 현탁된 이 액을 vortexing 한 후 1,000 $\mathrm{rpm}$ 에서 $5 \mathrm{~min}$ 동안 원심 분리하여 상층액을 활성 측정 효소액으 로 사용하였다. 96 well plate에 이 효소액을 $40 \mu \mathrm{L}$ 넣고 기질인 2 $\mathrm{mg} / \mathrm{mL} \mathrm{L}-\mathrm{DOPA} 100 \mu \mathrm{L}$ 를 첨가하였다. $37^{\circ} \mathrm{C}$ 에서 $1 \mathrm{~h}$ 동안 반응
을 진행시킨 뒤, microplate reader (Molecular Devices)를 이용하 여 $405 \mathrm{~nm}$ 에서 흡광도를 측정하였다. Tyrosinase의 활성도는 대 조군의 흡광도에 대한 백분율로 계산하였다.

\section{5) 총 melanin 합성량 측정}

Melanin 합성량 측정은 Hosoi et al. (1985) 방법을 변형하여 사 용하였다. B16F10 melanoma 세포를 24 well plate에 $1 \times 10^{5}$ cells/ well의 농도로 분주하고 $24 \mathrm{~h}$ 동안 배양한 다음, 생강나무 꽃 추출 물을 10-200 $\mu \mathrm{g} / \mathrm{mL}$ 처리한 후 $72 \mathrm{~h}$ 배양하였다. $72 \mathrm{~h}$ 배양한 후 각 well를 PBS로 세척한 후 $0.2 \mathrm{~N} \mathrm{NaOH}$ 용액 $400 \mu \mathrm{L}$ 를 첨가하고 $60^{\circ} \mathrm{C}$ 에서 $1 \mathrm{~h}$ 동안 용해하였으며, microplate reader (Molecular Devices)를 이용하여 $405 \mathrm{~nm}$ 에서 흡광도를 측정하였다.

6) $\alpha-\mathrm{MSH}$ 유도에 의한 tyrosinase 활성도 및 melanin 합성량에 미 치는 영향 측정

외부 자극에 따른 B16F10 melanoma 세포 내 tyrosinase의 활 성 및 과생성된 멜라닌에 대해 생강나무 꽃 추출물이 미치는 영향 을 알아보기 위해 외부자극제로 $\alpha-\mathrm{MSH} 200 \mathrm{nM}$ 을 사용하였다. 세포 생존율에 따라 농도 별로 조제한 생강나무 꽃 추출물을 전 처 리하고 $1 \mathrm{~h}$ 후 $200 \mathrm{nM} \alpha-\mathrm{MSH}$ 를 세포에 처리하여 $72 \mathrm{~h}$ 배양 후, tyrosinase 활성도 및 melanin의 합성량을 측정하였다.

\section{4. 생강나무 꽃 추출물의 주름 개선 효과}

\section{1) 세포주 배양}

본 실험에 사용한 human dermal fibroblast $(\mathrm{HDF})$ 세포는 한 국세포주은행(Korea)에서 분양 받아 사용하였다. $\mathrm{HDF}$ 세포주는 $10 \% \mathrm{FBS}$ 와 $1 \% \mathrm{P} / \mathrm{S}$ 를 넣은 $\mathrm{DMEM}$ 배지를 배양액으로 하여 $37^{\circ} \mathrm{C}$, $5 \% \mathrm{CO}_{2}$ 의 습윤화된 incubator에서 적응시켜 배양하였다.

\section{2) MTT assay에 의한 세포 생존율 측정}

$\mathrm{HDF}$ 세포를 24 well에 각 well 당 $1 \times 10^{5}$ cells/well을 분주하여 $24 \mathrm{~h}$ 배양하였다. $24 \mathrm{~h}$ 의 배양이 끝난 후 생강나무 꽃 추출물을 최종농도 $10-400 \mu \mathrm{g} / \mathrm{mL}$ 이 되게 배양액에 희석하여 부착 및 안정 화된 세포주에 공급하고 $48 \mathrm{~h}$ 동안 배양하였다. 배양완료 후 well 에 MTT 용액 $\left(5 \mathrm{mg} / \mathrm{mL}\right.$ in PBS)을 가해주고 다시 $37^{\circ} \mathrm{C}, 5 \% \mathrm{CO}_{2}$ 의 습윤 배양기에서 $4 \mathrm{~h}$ 동안 반응하여 MTT가 환원되도록 하였 다. 각 well에 생성된 formazan 결정을 $\mathrm{DMSO} 150 \mu \mathrm{L}$ 로 잘 녹여 서 microplate reader (Molecular Devices)를 이용하여 $540 \mathrm{~nm}$ 에 서 흡광도를 측정하였다.

\section{3) ELISA kit를 이용한 콜라겐의 합성량 측정}

Procollagen type I 콜라겐의 합성량 측정은 enzyme-linked immunosorbent assay (ELISA) kit (Takara, Japan)를 사용하여 측정하였다. $\mathrm{HDF}$ 세포를 24 well에 각 well당 $1 \times 10^{5}$ cells/well을 
분주하고 $24 \mathrm{~h}$ 배양하였다. $24 \mathrm{~h}$ 배양이 끝난 후 생강나무 꽃 추출 물을 첨가하여 $48 \mathrm{~h}$ 동한 배양하고 상층액을 회수하고, 그 후 회수 된 상층액을 이용하여 kit에서 제공된 96 well plate에 coating하 고, $4^{\circ} \mathrm{C}$ 에서 세척하고, tris phosphate buffered saline (TPBS) 에 녹인 $3 \%$ bovine serum albumin (BSA; Sigma-Aldrich)을 넣고 $2 \mathrm{~h}$ blocking하였다. Primary antibody인 anti-collagen antibody를 $37^{\circ} \mathrm{C}$ 에서 $90 \mathrm{~min}$ 처리한 후 TPBS로 3 회 세척하 고, secondary antibody인 anti-mouse IgG (whole mouse, alkaline phosphatase conjugated)를 $90 \mathrm{~min}$ 반응시킨 후 TPBS 로 3 회 세척하였다. Alkaline phosphatase substrate solution (1 $\mathrm{mg} / \mathrm{mL}$ p-nitrophenyl phosphate in diethanolamine buffer) 을 상온에서 $30 \mathrm{~min}$ 반응시킨 후 microplate reader (Molecular Devices)로 $405 \mathrm{~nm}$ 에서 흡광도를 측정하였다.

\section{5. 생강나무 꽃 추출물의 항균력 측정}

1) 균주 및 균주 배양

항균 실험에 사용한 균주는 피부 상재균 중 염증을 유발하는 $S$. epidermidis, S. aureus, P. acnes를 한국생명공학연구원 생물자 원센터(Korea)에서 구입하여 계대 배양하여 사용하였다. 균주 배 양을 위한 배지는 $S$, aureus와 $S$. epidermidis는 nutrient broth (Becton, Dickinson and Company, USA)를 사용하였으며 P. acnes는 reinforced clostridial broth (Becton, Dickinson and Company)를 사용하였다.

\section{2) 항균 활성 측정}

생강나무 꽃 추출물의 항균 활성은 실험 균주를 대상으로 paper disc diffusion 방법을 이용하여 측정하였다. 배양된 균주는 $1 \times 10^{7}$ $\mathrm{CFU} / \mathrm{mL}$ 으로 조절한 후 본 실험에 사용하였다. 평판배지에 배양 된 각 균주를 $100 \mu \mathrm{L}$ 씩 도말하여 준비하였고, 생강나무 꽃 에탄올, 열수 추출물을 각각 $0.5,1,5,10 \mathrm{mg} / \mathrm{disc}$ 농도로 $40 \mu \mathrm{L}$ 씩 paper disc (diameter 8 mm; Toyo Roshi Kaisha, Japan)에 천천히 흡수 시킨 뒤, 건조과정을 거쳐 용매를 휘발시켰다. 대조군으로는 에탄 올을 사용하였으며, 배양 후 disc 주변에 생성된 생육저해환(clear $\mathrm{zone})$ 의 직경 $(\mathrm{mm})$ 을 측정하였다.

\section{6. 통계처리}

본 연구의 모든 실험 결과는 3 회 이상 반복하여 평균값으로 나타 내었다 평균치와 표준오차로 표기하였고, 통계처리는 Statistical Package for the Social Sciences (SPSS version 12.0; IBM, USA)를 이용하여 one-way ANOVA 분석을 실시한 후 Duncan's multiple range test로 유의성 $(p<0.05)$ 을 검증하였다.

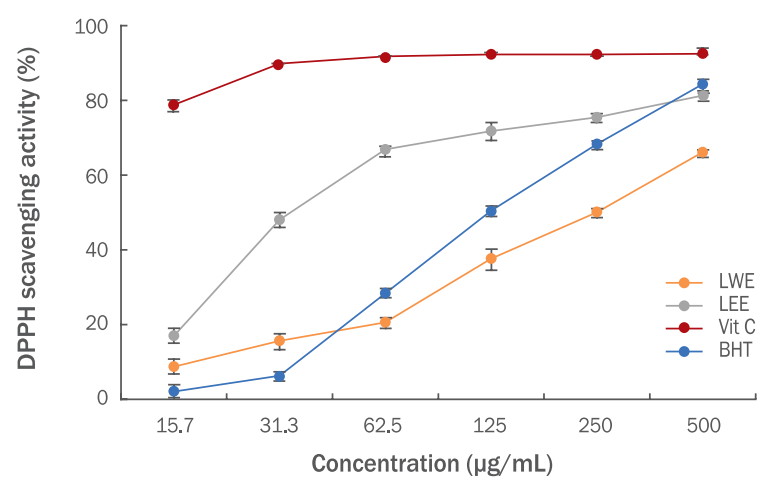

Figure 1. DPPH free radical scavenging activity of $L$. obtusiloba flower extracts.

L. obtusiloba flower extracts were incubated with DPPH solution at room temperature for $30 \mathrm{~min}$ in darkroom. DPPH free radical scavenging activity was determined by measurement of absorbance at $517 \mathrm{~nm}$. LWE and LEE increased DPPH scavenging activity in a dose-dependent manner. Vit $\mathrm{C}$ and BHT were used as positive controls. Each value was expressed as $\mathrm{M} \pm \mathrm{S}$.E. of triplicate determinations. L. obtusiloba, Lindera obtusiloba; DPPH, 2,2-diphenyl-1-picrylhydrazyl; LWE, L. obtusiloba flower water extracts; LEE, L. obtusiloba flower $70 \%$ ethanol extracts; Vit $\mathrm{C}$, vitamin $\mathrm{C}$; $\mathrm{BHT}$, butylated hydroxytoluene; $\mathrm{M} \pm \mathrm{S}$.E., mean \pm standard error.

\section{Results and Discussion}

\section{1. 생강나무 꽃 추출물의 항산화 활성}

1) $\mathrm{DPPH}$ 라디칼 소거 활성

$\mathrm{DPPH}$ 라디칼은 비교적 안정한 화합물로 항산화 활성을 갖는 물 질을 만나면 라디칼이 소거되어 탈색되는 점을 이용하여 항산화 활 성을 검정하는데 사용되는 물질이다. $\mathrm{DPPH}$ 라디칼 소거 활성법은 식물 추출물의 항산화 활성을 쉽게 측정할 수 있으며, 실제로 항산 화 활성과 연관성이 매우 높다고 알려져 있다(Jeong et al, 2006).

생강나무 꽃 열수 추출물과 에탄올 추출물을 농도별로 $\mathrm{DPPH}$ 용 액에 첨가하여 자유 라디칼 소거 활성 능력을 측정한 결과, 15.7$500 \mu \mathrm{g} / \mathrm{mL}$ 의 농도에서 열수 추출물은 각각 $8.71 \pm 1.80 \%, 15.64$ $\pm 0.71 \%, 20.58 \pm 0.40 \%, 37.63 \pm 0.59 \%, 50.08 \pm 1.05 \%, 66.16 \pm$ $1.07 \%$ 의 $\mathrm{DPPH}$ 자유 라디칼 소거 효과를 보였으며, 에탄올 추출 물은 $16.94 \pm 1.80 \%, 48.08 \pm 1.83 \%, 66.89 \pm 1.13 \%, 71.81 \pm 2.21 \%$, $75.47 \pm 0.77 \%, 81.33 \pm 0.51 \%$ 로 농도의존적으로 소거능이 증가하 였다(Figure 1).

Choi et al. (2003)의 연구에서는 밤꽃 추출물의 $17.22 \% \mathrm{DPPH}$ 소거능이 보고되었고, Koh et al. (2005)의 석류씨 추출물의 항산 화 측정 결과, 열수, 에탄올 추출물이 $1,000 \mu \mathrm{g} / \mathrm{mL}$ 농도에서 각각 $18.8 \%, 28.5 \%$ 의 소거능을 나타낸다고 보고하여 이와 비교해 볼 때 생강나무 꽃 열수 및 에탄올 추출물은 DPPH 소거능이 우수함을 알 수 있었으며, 천연 항산화제로서의 가능성을 확인할 수 있었다. 


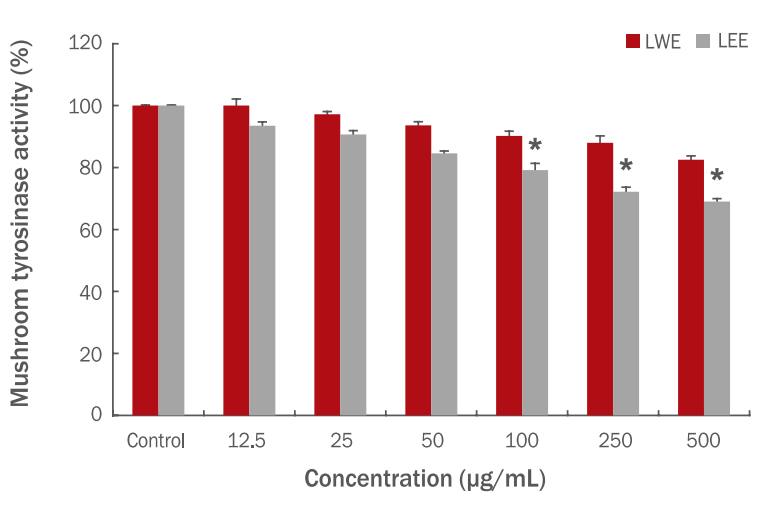

Figure 2. Inhibitory effects of $L$. obtusiloba flower extracts on mushroom tyrosinase activity in vitro.

To confirm the whitening effects of $L$. obtusiloba flower extracts, we measured mushroom tyrosinase activity in vitro. Both LWE and LEE decreased the tyrosinase activity in a dose-dependent manner. Each value was expressed as $\mathrm{M} \pm \mathrm{S}$.E. of triplicate determinations. Bar graphs with the asterisk $\left(^{*}\right)$ were significantly different compared with control by Duncan's multiple range test $(p<0.05)$. L. obtusiloba, Lindera obtusiloba; LWE, L. obtusiloba flower water extracts; LEE, L. obtusiloba flower $70 \%$ ethanol extracts; $\mathrm{M} \pm$ S.E., mean \pm standard error.

\section{2) 생강나무 꽃 추출물의 총 폴리페놀 및 플라보노이드 함량}

페놀성 화합물에 존재하는 phenolic hydroxy기는 단백질 등과 결 합하는 성질을 가지며 항산화, 항암 및 항균 효과 등의 다양한 생리 활성을 나타내는 것으로 알려져 있다. 일반적으로 총 폴리페놀 함량 이 증가할수록 항산화 등의 생리 활성이 증가하는 경향으로 보고된다 (Lee et al, 2012). 생강나무 꽃 열수, 에탄올 추출물의 총 페놀 함량을 측정하여 Table 1에 결과를 나타내었다. 표준물질로 tannic acid를 사 용하여 분석한 생강나무 꽃 열수, 에탄올 추출물의 총 페놀의 함량은 각각 $107.46 \pm 1.54 \mu \mathrm{g} / \mathrm{mL}, 152.00 \pm 1.64 \mu \mathrm{g} / \mathrm{mL}$ 으로 나타났다.

플라보노이드는 폴리페놀에 속하는 성분으로, 플라보노이드의 $\mathrm{C}_{6}-\mathrm{C}_{3}-\mathrm{C}_{6}$ 를 기본골격으로 하며 노란색 내지는 담황색을 나타내는 페놀계 화합물의 총칭으로 자연계에 널리 분포하고 있으며 폴리페놀 과 같이 채소류와 식물의 잎, 꽃, 과실, 줄기 및 뿌리 등 거의 모든 부 위에 함유되어 있는 것으로 알려져 있다(Kim et al., 2012).

생강나무 꽃 열수, 에탄올 추출물의 총 플라보노이드 함량을 측정 하여 Table 1에 결과를 나타내었다. Naringin을 표준물질로 분석한 생 강나무 꽃 열수, 에탄올 추출물의 총 플라보노이드의 함량은 105.94 $\pm 1.32 \mu \mathrm{g} / \mathrm{mL}, 145.27 \pm 1.52 \mu \mathrm{g} / \mathrm{mL}$ 으로 나타났다.

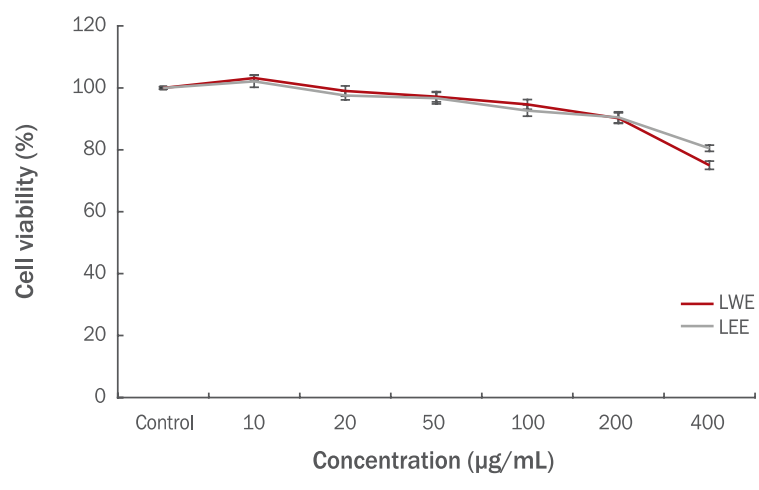

Figure 3. Effects of $L$. obtusiloba flower extracts on the viability of B16F10 melanoma cells.

B16F10 melanoma cells were cultured in the presence of various concentrations of L. obtusiloba flower extracts for $72 \mathrm{~h}$. There was no cytotoxicity of LWE and LEE from 10 to $200 \mu \mathrm{g} / \mathrm{mL}$. Each value was expressed as $\mathrm{M} \pm \mathrm{S}$.E. of triplicate determinations. $L$. obtusiloba, Lindera obtusiloba; LWE, L. obtusiloba flower water extracts; LEE, L. obtusiloba flower $70 \%$ ethanol extracts; M \pm S.E., mean \pm standard error.

\section{2. 생강나무 꽃 추출물의 미백 효과}

1) Mushroom tyrosinase 저해 활성

멜라닌 합성에 중요한 역할을 하는 효소인 tyrosinase의 활성 억제 작용은 버섯 tyrosinase를 효소원으로 하여 기질인 $\mathrm{L}-\mathrm{DOPA}$ 와의 반 응으로 생성된 L-dopaquinone의 흡광도를 측정하였다(Kim et al,, 2011). 생강나무 꽃 열수 및 에탄올 추출물의 tyrosinase 억제 효능 측 정 결과, Figure 2 와 같이 생강나무 꽃 열수 추출물은 $12.5,25,50$, $100,250,500 \mu \mathrm{g} / \mathrm{mL}$ 농도에서 $100.00 \%, 97.20 \%, 93.60 \%, 90.20 \%$, $88.00 \%, 82.50 \%$ 로, 에탄올 추출물은 $93.20 \%, 90.70 \%, 84.60 \%$, $79.20 \%, 77.20 \%, 69.00 \%$ 로 tyrosinase 활성이 농도의존적으로 감소 하는 경향을 나타내었다.

An et al. (2005)의 연구에서 진달래꽃 열수, 에탄올 추출물은 500 $\mathrm{ppm}$ 에서 각각 $12 \%, 24 \%$ 의 저해를 나타낸 결과와 비교하여 생강나무 꽃추출물의 tyrosinase 억제 활성이 우수함을 확인할 수 있었다.

\section{2) 세포 생존 능력 측정}

세포 수준의 연구에 많이 이용되고 있는 MTT assay는 세포증식 과 생존능의 in vitro 분석에 매우 유용하게 사용되고 있다(Bang et al, 2008). B16F10 melanoma 세포에 대한 생강나무 꽃 열수, 에 탄올 추출물의 세포 생존율과 실험에 사용될 유효농도 범위를 결정

Table 1. Total phenolics and total flavonoids content of $L$. obtusiloba flower extracts

\begin{tabular}{llc}
\hline & \multicolumn{1}{c}{ LWE } & LEE \\
Total phenolics & $107.46 \pm 1.54 \mu \mathrm{g} / \mathrm{mL}$ & $152.00 \pm 1.64 \mu \mathrm{g} / \mathrm{mL}$ \\
Total flavonoids & $105.94 \pm 1.32 \mu \mathrm{g} / \mathrm{mL}$ & $145.27 \pm 1.52 \mu \mathrm{g} / \mathrm{mL}$ \\
\hline
\end{tabular}

L. obtusiloba, Lindera obtusiloba; LWE, L. obtusiloba flower water extracts; LEE, L. obtusiloba flower 70\% ethanol extracts. 


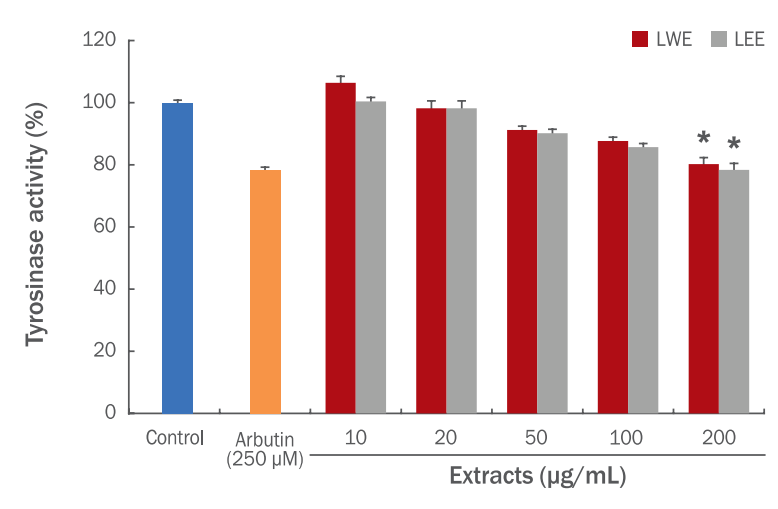

Figure 4. Inhibitory effects of $L$. obtusiloba flower extracts on tyrosinase activity in B10F10 melanoma cells.

To confirm the whitening effects of $L$. obtusiloba flower extracts, we measured tyrosinase activity in B16F10 melanoma cells. Both LWE and LEE decreased the tyrosinase activity in a dosedependent manner. In particular, $200 \mu \mathrm{g} / \mathrm{mL}$ LEE showed inhibition of tyrosinase activity similar to arbutin, a positive control. Each value was expressed as $\mathrm{M} \pm \mathrm{S}$.E. of triplicate determinations. Bar graphs with the asterisk $\left({ }^{*}\right)$ were significantly different compared with control by Duncan's multiple range test $(p<0.05)$. L. obtusiloba, Lindera obtusiloba; LWE, L. obtusiloba flower water extracts; LEE, L. obtusiloba flower $70 \%$ ethanol extracts; $\mathrm{M} \pm \mathrm{S}$.E., mean \pm standard error.

하기 위해 $10,20,50,100,200,400 \mu \mathrm{g} / \mathrm{mL}$ 의 농도로 처리하고 배 양한 후 MTT assay를 시행하였다. B16F10 melanoma 세포에 대 한 세포 생존율을 측정한 결과, $200 \mu \mathrm{g} / \mathrm{mL}$ 이하의 농도에서는 세 포 생존율이 $90 \%$ 이상으로 나타났다(Figure 3). 따라서 이 결과를 토대로 생강나무 꽃 열수, 에탄올 추출물의 세포에서의 tyrosinase 저해 활성 및 melanin 생합성, $\alpha-\mathrm{MSH}$ 유도에 의한 tyrosinase 활 성도 및 melanin 합성량에 미치는 영향에 대한 실험에서는 10-200 $\mu \mathrm{g} / \mathrm{mL}$ 의 농도 범위에서 진행하였다.

\section{3) B16F10 melanoma 세포에서 tyrosinase 저해 활성}

Tyrosinase는 동식물, 미생물 및 사람 등이 갖고 있는 polyphenol oxidase로, 멜라닌 합성 과정에서 속도를 제한하는 등 멜라닌 합성 의 주요한 조절적 역할을 하는 효소이다(Lee \& An, 2010). 이러한 멜라닌 생합성에 관여하는 주요 효소인 tyrosinase에 대한 영향을 $\mathrm{B} 16 \mathrm{~F} 10$ melanoma 세포에서 생강나무 꽃 열수 및 에탄올 추출물을 통해 확인한 결과는 Figure 4와 같다. 생강나무 꽃 열수 추출물은 $10,20,50,100,200 \mu \mathrm{g} / \mathrm{mL}$ 농도에서 $106.37 \%, 98.17 \%, 97.17 \%$, $87.66 \%, 80.21 \%$ 로, 에탄올 추출물은 $100.37 \%, 98.17 \%, 90.17 \%$, $85.66 \%, 78.34 \%$ 로 tyrosinase 활성이 억제됨을 확인하였다. 특히, 에탄올 추출물 $200 \mu \mathrm{g} / \mathrm{mL}$ 농도에서는 양성대조군인 arbutin과 유 사한 tyrosinase 저해능을 나타내어 생강나무 꽃 추출물이 효소실 험뿐만 아니라 세포 내 tyrosinase 활성 억제에도 효과가 있음을 확 인할 수 있었다. Bang et al. (2008)의 생강나무 잎 추출물은 50

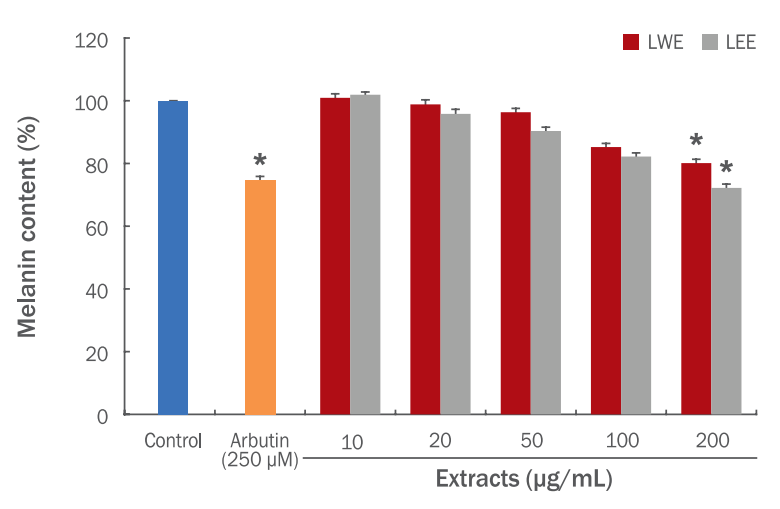

Figure 5. Inhibitory effects of L. obtusiloba flower extracts on melanin synthesis in B10F10 melanoma cells.

Effects of $L$. obtusiloba flower extracts on inhibition of melanin synthesis were confirmed in B16F10 melanoma cells, after the cells were treated with those indicated concentrations. LWE and LEE decreased the melanin content in a dose-dependent manner. In particular, inhibitory effects of $200 \mu \mathrm{g} / \mathrm{mL}$ LEE on melanin synthesis were better than those of arbutin, a positive control. Each value was expressed as $\mathrm{M} \pm$ S.E. of triplicate determinations. Bar graphs with the asterisk ( $\left.{ }^{*}\right)$ were significantly different compared with control by Duncan's multiple range test $(p<0.05)$. L. obtusiloba, Lindera obtusiloba; LWE, L. obtusiloba flower water extracts; LEE, L. obtusiloba flower $70 \%$ ethanol extracts; $\mathrm{M} \pm \mathrm{S}$.E., mean \pm standard error.

$\mu \mathrm{g} / \mathrm{mL}$ 에서 tyrosinase 활성 저해율은 $45.2 \%$ 으로 확인 되었지 만, 생강나무 꽃 에탄올 추출물 $200 \mu \mathrm{g} / \mathrm{mL}$ 농도에서는 대조물 질인 arbutin과 유사한 $78.34 \%$ 저해 활성율이 확인되었다.

\section{4) 생강나무 꽃 추출물이 melanin 생합성에 미치는 영향}

Melanin은 세포 내의 소기관인 ribosome에서 tyrosinase라는 효 소의 생합성에서 합성되기 시작한다. 이 효소의 작용으로 아미노산 의 일종인 tyrosine에서 몇 단계의 합성을 거쳐, 기저층의 melanin 세포 melanoma site라는 흑색소포 표면에 침착하여 검고 갈색 의 작은 melanin 입자가 만들어 진다(Hwang et al., 2012a). 피 부 melanin 합성 저해능은 피부 미백 효능의 중요한 지표로 알려 져 있다(Lee et al., 2014). 따라서 생강나무 꽃 열수 및 에탄올 추 출물의 B16F10 melanoma 세포에서의 melanin 생합성을 측정한 결과는 Figure 5 와 같이 나타내었다. 생강나무 꽃 열수 추출물은 $10,20,50,100,200 \mu \mathrm{g} / \mathrm{mL}$ 농도에서 $100.90 \%, 98.81 \%, 96.32 \%$, $85.21 \%, 80.10 \%$ 로, 에탄올 추출물은 $101.90 \%, 95.82 \%, 90.32 \%$, $82.21 \%, 72.20 \%$ 로 melanin 생합성량이 농도의존적으로 감소함 을 확인하였다. 특히, 에탄올 추출물은 $200 \mu \mathrm{g} / \mathrm{mL}$ 농도에서 양 성대조군인 arbutin 보다 다소 높은 melanin 생합성 억제 효과를 나타냈다. 이는 Hwang et al. (2012b)의 생강나무 잎 추출물보다 는 낮은 melanin 생합성 저해 효과이지만 생강나무 꽃 추출물도 melanin 합성억제 가능성이 있음을 확인할 수 있었다. 
A

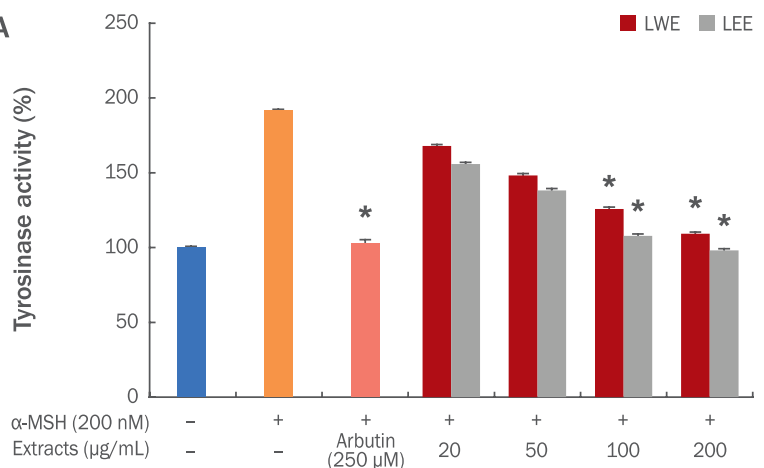

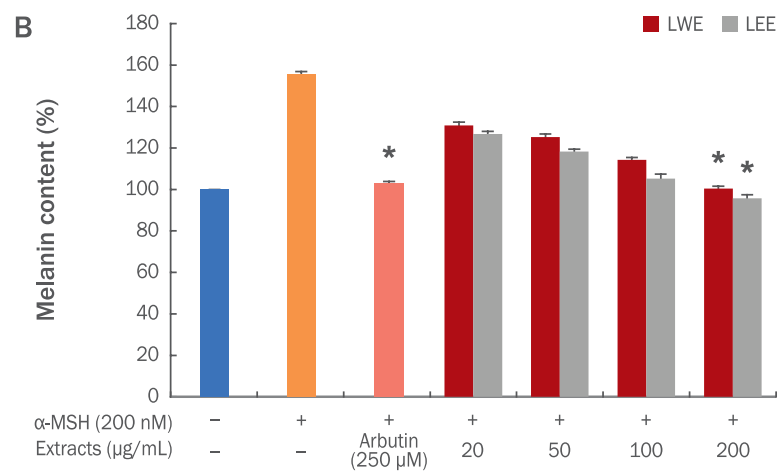

Figure 6. Inhibitory effects of $L$. obtusiloba flower extracts on tyrosinase activity and melanin synthesis in B16F10 melanoma cells stimulated by $\alpha-M S H$.

After treatment of L. obtusiloba flower extracts for $1 \mathrm{~h}$ at the indicated concentrations, B16F10 cells were stimulated with or without $\alpha$-MSH.Then, we confirmed inhibitory effects of $L$. obtusiloba flower extracts on tyrosinase activity (A) and melanin synthesis (B). The $\alpha$-MSH-treated group rose to $191.47 \%$ and $155.69 \%$ compared with each control in tyrosinase activity and melanin content, respectively. However, LWE and LEE decreased tyrosinase activity and melanin content in a dose-dependent manner. In the case of $200 \mu \mathrm{g} / \mathrm{mL} \mathrm{LEE}$, the inhibitory effects on tyrosinase and melanin were better than those of arbutin used as a positive control. Each value was expressed as $\mathrm{M} \pm$ S.E. of triplicate determinations. Bar graphs with the asterisk $(*)$ were significantly different compared with control by Duncan's multiple range test $(p<0.05)$. L. obtusiloba, Lindera obtusiloba; LWE, L. obtusiloba flower water extracts; LEE, L. obtusiloba flower 70\% ethanol extracts; $\alpha-\mathrm{MSH}, \alpha$-melanocyte-stimulating hormone; $\mathrm{M} \pm \mathrm{S}$.E., mean \pm standard error.

5) $\alpha-\mathrm{MSH}$ 유도에 의한 tyrosinase 활성도 및 melanin 합성량에 미치는 영향 측정

$200 \mathrm{nM} \alpha-\mathrm{MSH}$ 에 의해 유도된 멜라닌 합성조건에서 생강나 무 꽃 열수, 에탄올 추출물의 억제 효과를 확인하기 위하여, 생 강나무 꽃 열수, 에탄올 추출물 $(20,50,100,200 \mu \mathrm{g} / \mathrm{mL})$ 을 전 처리하고 $1 \mathrm{~h}$ 후 $200 \mathrm{nM} \alpha-\mathrm{MSH}$ 를 세포에 처리하여 $72 \mathrm{~h}$ 배 양 후, 세포내 tyrosinase 활성과 melanin 합성량을 조사하였다. Tyrosinase 활성 효과는 Figure 6A에서 보는 바와 같이 $200 \mathrm{nM}$ $\alpha-\mathrm{MSH}$ 만 처리한 경우에는 tyrosinase 활성이 대조군에 비하 여 $191.47 \%$ 으로 증가한 것을 확인할 수 있었다. $\alpha-\mathrm{MSH}$ 처리 후 양성대조군인 arbutin $(250 \mu \mathrm{M})$ 을 처리하였을 때 $102.94 \%$ 로 나 타나 tyrosinase 활성 억제 효과가 확인되었다. 생강나무 꽃 열 수 추출물의 경우 $20,50,100,200 \mu \mathrm{g} / \mathrm{mL}$ 농도를 처리했을 때 각각 $167.88 \%, 148.26 \%, 125.85 \%, 109.21 \%$, 에탄올 추출물은 $155.88 \%, 138.26 \%, 107.85 \%, 98.10 \%$ 로 $\alpha-\mathrm{MSH}$ 를 단독으로 처
리한 경우에 비하여 농도의존적으로 tyrosinase 활성이 감소함을 확인하였다. 특히, 생강나무 꽃 에탄올 추출물 $200 \mu \mathrm{g} / \mathrm{mL}$ 농도에 서는 양성대조군인 arbutin보다 tyrosinase 활성 억제 효과가 높게 확인되었다.

Melanin 합성량을 조사한 결과, Figure $6 \mathrm{~B}$ 에서 보는 바와 같이 $200 \mathrm{nM} \alpha-\mathrm{MSH}$ 만 처리한 경우에는 melanin 함량이 대조군에 비 하여 $155.69 \%$ 으로 증가한 것을 확인할 수 있었으며, $20,50,100$, $200 \mu \mathrm{g} / \mathrm{mL}$ 농도에서 열수 추출물은 $130.82 \%, 125.31 \%, 114.24 \%$, $100.42 \%$ 로 melanin 합성량이 감소하였다. 에탄올 추출물 20,50 , $100,200 \mu \mathrm{g} / \mathrm{mL}$ 을 처리한 경우에는 $126.80 \%, 118.31 \%, 105.22 \%$, $95.71 \%$ 로 melanin 합성 억제 효과가 확인되어 생강나무 꽃 열수, 에탄올 추출물을 처리한 경우에는 $\alpha-\mathrm{MSH}$ 단독 처리한 경우에 비 하여 농도의존적으로 melanin 합성이 억제되는 것으로 나타났다. 특히 생강나무 꽃 에탄올 추출물은 양성대조군인 arbutin 보다 melanin 합성 억제능이 높은 것으로 나타났다. 따라서 생강나무 꽃

Table 2. Anti-bacterial activities of $L$. obtusiloba flower extracts

\begin{tabular}{lcccccccccc}
\hline & \multicolumn{8}{c}{ Inhibition zone diameter $(\mathrm{mm})$} \\
\cline { 2 - 11 } Bacteria & \multicolumn{2}{c}{$0.5 \mathrm{mg} /$ disc } & \multicolumn{2}{c}{$1 \mathrm{mg} /$ disc } & \multicolumn{2}{c}{$5 \mathrm{mg} /$ disc } & \multicolumn{2}{c}{$10 \mathrm{mg} /$ disc } & Control \\
\cline { 2 - 11 } & LWE & LEE & LWE & LEE & LWE & LEE & LWE & LEE & Ethanol \\
S. epidermidis & 8 & 14 & 8 & 15 & 8 & 16 & 8 & 18 & - \\
S. aureus & 8 & 8 & 8 & 8 & 8 & 10 & 8 & 12 & - \\
P. acnes & 8 & 10 & 8 & 11 & 12 & 12 & 13 & 16 & - \\
\hline
\end{tabular}

L. obtusiloba, Lindera obtusiloba; LWE, L. obtusiloba flower water extracts; LEE, L. obtusiloba flower 70\% ethanol extracts; S. epidermidis, Staphylococcus epidermidis; S. aureus, Staphylococcus aureus; P. acnes, Propionibacterium acnes.

Diameter of paper disc: $8 \mathrm{~mm}$. 


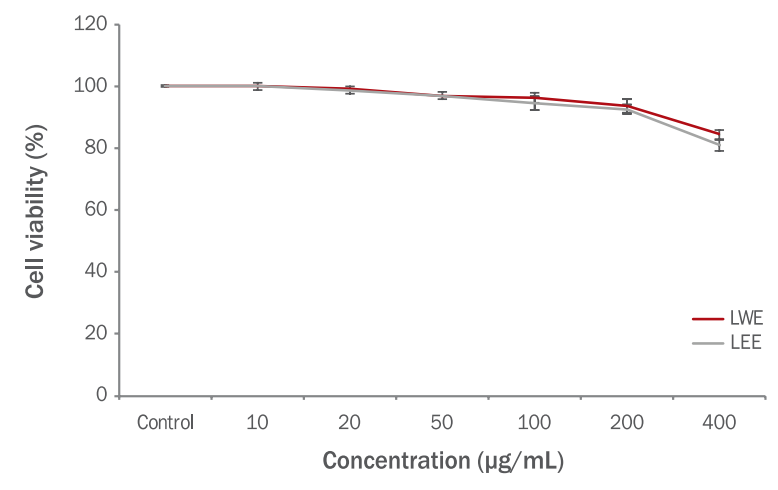

Figure 7. Effects of L. obtusiloba flower extracts on the viability of HDF cells.

The cells were cultured in the presence of various concentrations of $L$. obtusiloba flower extracts for $48 \mathrm{~h}$. There was no cytotoxicity of LWE and LEE from 10 to $200 \mu \mathrm{g} / \mathrm{mL}$. Each value was expressed as $\mathrm{M} \pm \mathrm{S}$.E. of triplicate determinations. L. obtusiloba, Lindera obtusiloba; LWE, L. obtusiloba flower water extracts; LEE, L. obtusiloba flower $70 \%$ ethanol extracts; HDF, human dermal fibroblast; $\mathrm{M} \pm \mathrm{S}$.E., mean \pm standard error.

열수, 에탄올 추출물은 $\alpha-\mathrm{MSH}$ 에 의해 유도된 tyrosinase 활성 및 melanin 합성에 억제 효과를 나타내는 것으로 사료된다.

\section{3. 생강나무 꽃 추출물의 주름 개선 활성}

1) 세포 생존 능력 측정

$\mathrm{HDF}$ 세포에 대한 생강나무 꽃 열수, 에탄올 추출물의 세포 생 존율과 실험에 사용될 유효농도 범위를 결정하기 위해 10-400 $\mu \mathrm{g} /$ $\mathrm{mL}$ 의 농도로 처리하고 배양한 후 MTT assay를 시행하였다. $\mathrm{HDF}$ 세포에 대한 세포 생존율을 측정한 결과, $200 \mu \mathrm{g} / \mathrm{mL}$ 이하의 농도 에서는 세포 생존율이 $90 \%$ 이상으로 나타났다(Figure 7). 그러므 로 생강나무 꽃 열수, 에탄올 추출물의 procollagen 합성에 대한 실 험은 $10-200 \mu \mathrm{g} / \mathrm{mL}$ 농도 범위에서 진행하였다.

\section{2) Procollagen 합성}

진피층은 $90 \%$ 가 collagen으로 구성되어 있어 collagen의 감소 는 피부노화와 밀접한 관계를 가지고 있다. 탄력섬유인 collagen은 망상구조로 존재하며 털을 세워주는 기모근과 함께 진피를 지지하 고 있으며 지금까지 19 가지 아형이 알려져 있고, 1,500 개의 아미노 산으로 구성된 $\alpha$-chain을 가지는 동종 또는 이중 삼중나선 구조를 형성한다(Park et al., 2008).

콜라겐은 피부의 주름형성과 밀접한 연관이 있으며 콜라겐이 부 족할 경우 주름이 유발될 수 있다. 따라서 콜라겐의 합성을 촉진시 킬 수 있는 소재는 탄력 있는 피부를 만들어 주는 화장품 원료로서 사용 가능하다고 생각하여(Park et al., 2008), 생강나무 꽃 열수, 에탄올 추출물의 collagen 합성 실험을 하였다. 실험 결과 Figure 8 에서 나타난 바와 같이 생강나무 꽃 열수 추출물은 $20,50,100$,

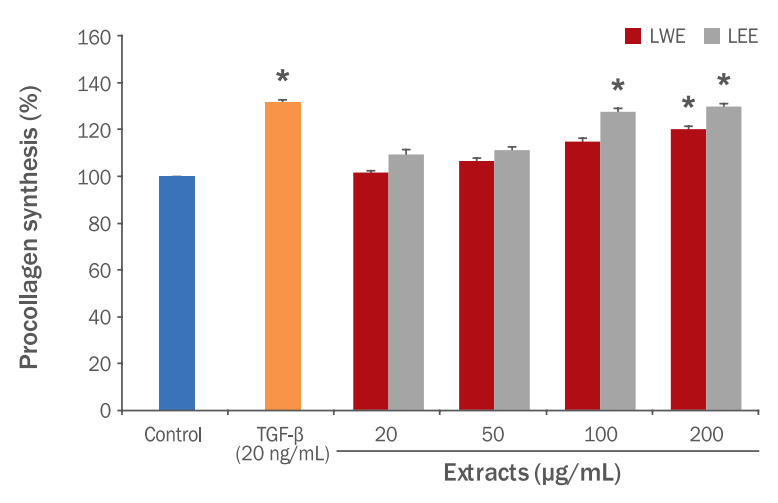

Figure 8. Effects of $L$. obtusiloba flower extracts on a procollagen biosynthesis in HDF cells.

Effects of L. obtusiloba flower extracts on procollagen synthesis were confirmed in HDF cells, after the cells were treated with those indicated concentrations. LWE and LEE increased the procollagen content in a dose-dependent manner. In particular, promotive effects of $200 \mu \mathrm{g} / \mathrm{mL}$ LEE on procollagen synthesis were similar to those of TGF- $\beta$, a positive control. Each value was expressed as $\mathrm{M} \pm \mathrm{S}$.E. of triplicate determinations. Bar graphs with the asterisk $\left({ }^{*}\right)$ were significantly different compared with control by Duncan's multiple range test $(p<0.05)$. L. obtusiloba, Lindera obtusiloba; LWE, L. obtusiloba flower water extracts; LEE, L. obtusiloba flower $70 \%$ ethanol extracts; HDF, human dermal fibroblast; TGF- $\beta$, transforming growth factor beta; $M \pm S$.E., mean \pm standard error.

$200 \mu \mathrm{g} / \mathrm{mL}$ 농도에서 procollagen 합성량이 $101.71 \%, 106.61 \%$, $114.92 \%, 120.30 \%$ 으로 확인되었으며, 에탄올 추출물의 경우 $109.41 \%, 111.32 \%, 127.71 \%, 130.00 \%$ 로 procollagen이 증가하여 $200 \mu \mathrm{g} / \mathrm{mL}$ 농도에서는 양성대조군인 transforming growth factor beta (TGF- $\beta$ )와 유사하게 procollagen 생합성이 촉진되었다.

\section{4. 생강나무 꽃 추출물의 항균 활성}

피부 상재균인 $S$. epidermidis, $S$. aureus, P. acnes에 대해 생강 나무 꽃 열수 및 에탄올 추출물의 항균 효과를 측정한 결과는 Table 2 와 같이 나타났다. 생강나무 꽃 열수 추출물은 $S$. epidermidis, $S$. aureus 균에 대한 항균 효과는 나타나지 않았으나, P. acnes 균에 서는 $5,10 \mathrm{mg} / \mathrm{disc}$ 의 농도로 처리했을 때 각각 $12,13 \mathrm{~mm}$ 의 clear zone을 형성하였다. 생강나무 꽃 에탄올 추출물의 항균 활성은 농도 의존적으로 clear zone이 나타났다. 염증을 유발하는 피부 상재균에 대한 생강나무 꽃 에탄올 추출물의 항균 효과를 paper disc로 측정 한 결과, $S$. epidermidis 균에 대해서는 $0.5,1,5,10 \mathrm{mg} / \mathrm{disc}$ 의 농도 에서 각각 $14,15,16,18 \mathrm{~mm}$ 의 clear zone이 확인되었다. S. aureus 균에 대해서는 $5,10 \mathrm{mg} / \mathrm{disc}$ 의 농도에서 각각 $10,12 \mathrm{~mm}$ 의 항균 활성이 확인되었다. 여드름을 유발하는 P. acnes 균에서는 0.5, 1, 5, $10 \mathrm{mg} / \mathrm{disc}$ 의 농도에서 $10,11,12,16 \mathrm{~mm}$ 의 clear zone이 나타났다. 


\section{Conclusion}

본 연구에서는 생강나무 꽃의 약리 활성 효능을 확인하고, 이 를 천연화장품 소재에 응용하기 위하여 생강나무 꽃을 열수 및 $70 \%$ 에탄올로 추출하여 $\mathrm{DPPH}$ 라디칼 소거 활성, 폴리페놀 및 플라보이드 함량을 측정하였다. 미백 효능을 확인하기 위해서는 mushroom tyrosinase 활성 저해 측정, B16F10 melanoma 세포 에서 tyrosinase 저해 활성, melanin 생합성에 미치는 영향을 측 정하였다. 또한, $\alpha-\mathrm{MSH}$ 의해 유도된 B16F10 melanoma 세포의 tyrosinase 활성 및 melanin 합성량에 미치는 영향도 측정하였다. 생강나무 꽃의 주름 개선 효과를 확인하기 위해서는 procollagen 합성을 측정하였으며, 피부 상재균에 대한 항균 활성도 확인하였다.

항산화 활성은 생강나무 꽃 열수 추출물보다 에탄올 추출물이 더욱 우수하였으며, 미백 효과와 관련해서는 에탄올 추출물을 500 $\mu \mathrm{g} / \mathrm{mL}$ 처리했을 때 tyrosinase 활성이 control 대비 $31.00 \%$ 감 소하였으며, B16F10 melanoma 세포에서도 tyrosinase 활성 및 melanin 생합성 저해 효과가 우수하였고, $\alpha-\mathrm{MSH}$ 에 의해 유도된 B16F10 melanoma 세포에서도 tyrosinase 활성 및 melanin 생합 성 저해 효과도 양성대조군인 arbutin 보다 높게 확인되었다.

생강나무 꽃의 주름 개선 효과를 확인하기 위해 procollagen 합 성을 측정한 결과, 농도의존적으로 procollagen 생합성량이 증가하 였고, 특히 생강나무 꽃 에탄올 추출물 $200 \mu \mathrm{g} / \mathrm{mL}$ 에서는 control 대비 $130.00 \%$ 의 procollagen 합성량을 나타내었다.

마지막으로 생강나무 꽃의 피부 상재균에 대한 항균 활성을 측 정한 결과, S. epidermidis, P. acnes 균에 대한 항균 효과가 높게 나타났다.

이러한 결과를 바탕으로 생강나무 꽃 추출물은 미백, 주름 개선 및 항균 효과를 가진 천연 기능성 화장품 소재로서의 응용 가능성 이 매우 높은 것으로 판단된다.

\section{Acknowledgement}

이 논문은 2017년도 남부대학교 학술연구비의 지원에 의해 수행 된 연구임.

\section{References}

An BJ, Lee CE, Son JH, Lee JY, Choi GH, Park TS. Antioxidant, anticancer and tyrosinase inhibition activities of extracts from Rhododendron mucronulatum T. Applied Biological Chemistry, 48: 280-284, 2005.

Bang CY, Won EK, Park KW, Lee GW, Choung SY. Antioxidant activities and whitening effect from Lindera obtusiloba BL. extract. Yakhak Hoeji, 52: 355-360, 2008.
Blois MS. Antioxidant determinations by the use of a stable free radical. Nature, 181: 1199-1200, 1958.

Choi CS, Song ES, Kim JS, Kang MH. Antioxidative activities of Castanea crenata Flos. methanol extracts. Korean Journal of Food Science and Technology, 35: 1216-1220, 2003.

Folin O, Denis W. A colorimetric method for the determination of phenols (and phenol derivatives) in urine. The Journal of Biological Chemistry, 22: 305-308, 1915.

Han NK, Park CM, Kwon JC, Joung MS, Choi JW. Whitening effect of Fagopyrum tataricum extract. Journal of the Society of Cosmetic Scientists of Korea, 40: 179-186, 2014.

Hong JH. Physiological activities of leaf and twig extracts from Lindera obtusiloba Blume. Korean Journal of Food and Cookery Science, 29: 573-580, 2013.

Hosoi J, Abe E, Suda T, Kuroki T. Regulation of melanin synthesis of B16 mouse melanoma cells by 1 alpha, 25-dihydroxyvitamin D3 and retinoic acid. Cancer Research, 45: 1474-1478, 1985.

Hwang EY, Kim DH, Hwang JY, Kim HJ, Park TS, Lee IS, Son $\mathrm{JH}$. A study on the depigmenting effect of Carthamus tinctorius seed, Cyperus rotundus and Schizonepeta tenuifolia extracts. Korean Journal of Food Science and Technology, 44: 76-81, 2012a.

Hwang JY, Park TS, Kim DH, Hwang EY, Lee JN, Lee JY, Lee GT, Lee K, Son JH. Anti-wrinkle compounds isolated from the seeds of Arctium lappa L. Journal of Life Science, 22: 1092-1098, 2012b.

Hwang JY, Park TS, Son JH. Whitening effect of extracts and fractions from Diospyros kaki calyx. Journal of Life Science, 23: 383-388, 2013.

Hwang KA, Kim KS, Kim NW, Shin SR. Changes on the components of Lindera obtusiloba BL. leaf teas by manufacturing process. Korean Journal of Food Preservation, 10: 488-492, 2003.

Hwang KA, Shin SR, Kim KS. Changes on the flavor components in the leaf teas of Lindera obtusiloba BL. by processing methods. Korean Journal of Food Preservation, 12: 68-74, 2005.

Jang HI, Heo EJ, Cheong KJ. A study of the whitening activities for skin between Phyllostachys pubescens and Lactobacillus fermented Phyllostachys pubescens extracts as cosmetic ingredient. Journal of the Korean Society of Cosmetology, 
21: 406-413, 2015.

Jeon JM, Yoo DS, Cheon JW, Kwon SS, Jeon SH, Park SN. Antiaging effect of Inula britannica var. chinensis flower extract according to the extraction temperature. Journal of the Society of Cosmetic Scientists of Korea, 40: 109-120, 2014.

Jeong GT, Lee KM, Park DH. Study of antimicrobial and antioxidant activities of Rumex crispus extract. Korean Chemical Engineering Research, 44: 81-86, 2006.

Joo DH, Yoo DH, Lee SY, Lee JY. Whitening effect of Astragalus membranceus Bunge water extract and development of cosmeceutical. Journal of the Korean Society of Cosmetology, 21: 888-894, 2015.

Kim BY, Park SH, Park BJ, Kim JJ. Whitening effect of Androsace umbellata extract. Journal of the Society of Cosmetic Scientists of Korea, 41: 21-26, 2015.

Kim EJ, Choi JY, Yu M, Kim MY, Lee S, Lee BH. Total polyphenols, total flavonoid contents, and antioxidant activity of Korean natural and medicinal plants. Korean Journal of Food Science and Technology, 44: 337-342, 2012.

Kim KY, Lee EJ, Whang WK. Screening of whitening and antiwrinkle efficacy of Peucedani japonici radix. Journal of the Korean Society of Cosmetology, 19: 925-930, 2013.

Kim SH, Do JS, Chung HJ. Antimicrobial activities of Lindera obtusiloba Blume and Zanthoxylum piperitum DC extracts. Korean Journal of Food Preservation, 21: 427-433, 2014.

Kim SH, Son JH, Lee SH. Inhibitory effects of water extract of Lindera obtusiloba on the mast cell-mediated allergic inflammation. Korean Journal of Pharmacognosy, 40: 233237, 2009.

Kim TH, Kim JM, Baek JM, Kim TW, Kim DJ, Park JH, Choe M. Antioxidant and whitening effects of Agrimonia pilosa Ledeb water extract. Korean Journal of Medicinal Crop Science, 19: 177-184, 2011.

Koh JH, Hwang MO, Moon JS, Hwang SY, Son JY. Antioxidative and antimicrobial activities of pomegranate seed extracts. Korean Journal of Food and Cookery Science, 21: 171-179, 2005.

Kwon DJ, Kim JK, Bae YS. Essential oils from leaves and twigs of Lindera obtusiloba. Journal of Korean Forest Society, 96: 6569, 2007.

Lee JY, Ahn EK, Ko HJ, Cho YR, Ko WC, Jung YH, Choi KM, Choi MR, Oh JS. Anti-melanogenic, anti-wrinkle, antiinflammatory and anti-oxidant effects of Xylosma congesta leaf ethanol extract. Journal of Applied Biological Chemistry,
57: 365-371, 2014.

Lee JY, An BJ. Whitening and anti-wrinkle effects of Prunus persica Flos. Journal of Applied Biological Chemistry, 53: 154-161, 2010.

Lee MY, Yoo MS, Whang YJ, Jin YJ, Hong MH, Pyo YH. Vitamin $\mathrm{C}$, total polyphenol, flavonoid contents and antioxidant capacity of several fruit peels. Korean Journal of Food Science and Technology, 44: 540-544, 2012.

Martínez-Esparza M, Jiménez-Cervantes C, Solano F, Lozano JA, García-Borrón JC. Mechanisms of melanogenesis inhibition by tumor necrosis factor-alpha in B16/F10 mouse melanoma cells. The FEBS Journal, 255: 139-146, 1998.

Moon $\mathrm{HI}$, Lee JH. Volatile aromatic components of ginger (Zingiber officinalis Roscoe) rhizomes and Japanese spice bush (Lindera obtusiloba BL). Korean Journal of Crop Science, 42: 7-13, 1997.

Park CM, Lee SY, Joung MS, Choi JW. Anti-wrinkle effect of 3-O-cetyl-L-ascorbic acid. Journal of the Society of Cosmetic Scientists of Korea, 34: 303-309, 2008.

Park KJ, Park SH, Kim JK. Anti-wrinkle activity of Lindera obtusiloba extract. Journal of the Society of Cosmetic Scientists of Korea, 35: 317-323, 2009.

Swain T, Hillis WE. The phenolic constituents of Prunus domestica: I.-the quantitative analysis of phenolic constituents. Journal of the Science of Food and Agriculture, 10: 63-68, 1959.

Won DH, Han SB, Hwang JP, Kim SJ, Park J, Park SN. Antioxidative effect and tyrosinase inhibitory activity of Lindera obtusiloba Blume extracts. Journal of the Society of Cosmetic Scientists of Korea, 38: 297-304, 2012.

Yagi A, Kanbara T, Morinobu N. Inhibition of mushroomtyrosinase by aloe extract. Planta Medica, 53: 515-517, 1987.

Yoo Y, Park EY, Kim YC. Antioxidative ability and whitening efficacy of peel's water extracts from plum (hongrosen and hollywood). Journal of the Korean Society of Cosmetology, 19: 516-523, 2013.

Yun H, Lee YJ, Seo HW, Park KJ, Ko HN, Cha DS, Kwon J, Jeon $\mathrm{H}$, Kim KS. Effect of Lindera obtusiloba extract on cancer metastasis. The Journal of Korean Oriental Internal Medicine, 33: 405-417, 2012. 


\section{국문초록}

\section{생강나무 꽃 추출물의 화장품 소재로서의 응용 가능성}

유현아, 김춘득

남부대학교 향장미용학과, 광주, 한국

목적: 본 연구에서는 생강나무 꽃의 약리 활성 효능을 확인하여 천연화장품 소재로서의 응용 가능성을 검증하고자 하였다. 방법: 생강나무 꽃을 열수 및 70\% 에탄올로 추출하여 항산화, 미백, 주름 개선, 항균 활성을 측정하였다. 결과: 생강나무 꽃 에 탄올 추출물 $500 \mu \mathrm{g} / \mathrm{mL}$ 에서는 81.33\%의 2,2-diphenyl-1-picrylhydrazyl (DPPH) 라디칼 소거능이 나타났고, 폴리페놀과 플 라보노이드 함량은 각각 $152.00,145.27 \mu \mathrm{g} / \mathrm{mL}$ 로 에탄올 추출물이 열수 추출물보다 높게 나타났다. 생강나무 꽃의 미백 효과 는 에탄올 추출물이 $500 \mu \mathrm{g} / \mathrm{mL}$ 농도에서 tyrosinase 활성을 control 대비 $31.00 \%$ 억제하였으며, B16F10 melanoma 세포에서 도 tyrosinase 활성 및 melanin 생합성 저해 효과가 우수하였고, $\alpha$-melanocyte-stimulating hormone $(\alpha-\mathrm{MSH})$ 유도에 의한 tyrosinase 활성 및 melanin 생합성 저해 효과도 양성대조군인 arbutin 보다 높게 확인되었다. 생강나무 꽃의 주름 개선 효과를 확 인하기 위해 procollagen 합성을 측정한 결과, 에탄올 추출물 $200 \mu \mathrm{g} / \mathrm{mL}$ 이 control 대비 $130.00 \%$ 의 procollagen 생합성량을 나타 내었다. 마지막으로 생강나무 꽃 추출물의 Staphylococcus epidermidis (S. epidermidis), Staphylococcus aureus (S. aureus), Propionibacterium acnes (P. acnes) 균에 대한 항균 활성을 측정한 결과, 에탄올 추출물의 $S$. epidermidis, P. acnes균에 대한 항균 효과가 우수하였다. 결론: 생강나무 꽃 추출물은 미백 및 주름 개선, 항균 효과를 가진 천연 기능성 화장품 소재로의 응용 가능성이 높은 것으로 판단된다.

핵심어: 생강나무, 항산화, 미백, 항균, 화장품

이 논문은 2017년도 남부대학교 학술연구비의 지원에 의해 수행된 연구임.

\section{참고문헌}

고종호, 황명오, 문주수, 황성연, 손종연. 석류씨 추출물의 항산화 및 항균활성. 한국식품조리과학회지, 21: 171-179, 2005. 권동주, 김진규, 배영수. 생강나무 잎과 가지의 정유성분. 한국임학회지, 96: 65-69, 2007.

김경영, 이은주, 황완균. 식방풍의 미백 및 주름개선 효과 탐색. 한국미용학회지, 19: 925-930, 2013.

김보윤, 박성하, 박병준, 김진준. 봄맞이 추출물의 미백 효능 연구. 대한화장품학회지, 41: 21-26, 2015.

김상현, 손준호, 이승호. 생강나무 추출물의 알레르기성 염증반응 억제 효과. 생약학회지, 40: 233-237, 2009.

김세훈, 도정선, 정현정. 생강나무(Lindera obtusiloba Blume)와 초피나무(Zanthoxylum piperitum DC) 추출물의 항균활성.

한국식품저장유통학회지, 21: 427-433, 2014.

김은진, 최주연, 유미리, 김미영, 이상현, 이복희. 자생식물과 생약자원 추출물의 폴리페놀, 플라보노이드 함량 및 항산화 활

성 탐색. 한국식품과학회지, 44: 337-342, 2012.

김태혁, 김정미, 백종미, 김태우, 김대중, 박정해, 최면. 짚신나물 물 추출물의 항산화 활성 및 미백효과에 관한 연구. 한국약

용작물학회지, 19: 177-184, 2011.

문형인, 이재학. 생강과 생강나무의 향기성분조성 비교. 한국작물학회지, 42: 7-13, 1997.

박금주, 박승희, 김재기. 생강나무 추출물의 광노화에 의한 주름형성 억제 효과. 대한화장품학회지, 35: 317-323, 2009.

박창민, 이순영, 정민석, 최종완. 3-O-cetyl-L-ascorbic acid의 주름 개선 효과. 대한화장품학회지, 34: 303-309, 2008.

방채영, 원은경, 박권우, 이광원, 정세영. 생강나무 추출물의 항산화 활성과 미백효과. 약학회지, $52: 355-360,2008$.

원두현, 한샛별, 황준필, 김수지, 박진오, 박수남. 생강나무 추출물의 항산화 효과 및 타이로시네이즈 저해 활성. 대한화장품 
학회지, 38: 297-304, 2012.

유용기, 박은예, 김영철. 자두(홍로센, 헐리웃) 과피 열수추출물의 항산화능과 피부미백 효능 비교. 한국미용학회지, 19 :

516-523, 2013.

윤혁, 이용재, 서현원, 박경재, 고하늘, 차동석, 권진, 전훈, 김강산. 생강나무 추출물의 암전이 억제효과. 대한한방내과학회 지, 33: 405-417, 2012.

이민영, 유미소, 황유정, 진유정, 홍명희, 표명희. 과일 껍질의 비타민 C, 폴리페놀, 플라보노이드 함량과 항산화 활성. 한국식 품과학회지, 44: 540-544, 2012.

장혜인, 허은주, 정광조. 화장품 소재로서 맹종죽과 발효 맹종죽의 피부미백 활성 연구. 한국미용학회지, $21: 406-413$, 2015.

전지민, 유대성, 천종우, 권순식, 전소하, 박수남. 추출 온도에 따른 금불초 꽃 추출물의 항노화 효능. 대한화장품학회지, 40 : 109-120, 2014.

주다혜, 유단희, 이수연, 이진영. 황기 물 추출물의 미백 효과와 기능성 화장품으로서의 개발. 한국미용학회지, 21: 888-894, 2015.

최창숙, 송은승, 김장수, 강명화. 밤꽃(Castanea Crenata Flos.) 메탄올 추출물의 항산화 효과. 한국식품과학회지, 35: $1216-$ 1220, 2003.

한나경, 박창민, 권주찬, 정민석, 최종완. 쓴메밀 추출물의 미백 개선 효과. 대한화장품학회지, 40: 179-186, 2014.

홍주헌. 생강나무 잎 및 가지 추출물의 생리활성. 한국식품조리과학회지, 29: 573-580, 2013.

황경아, 김광수, 김남우, 신승렬. 제조방법에 따른 생강나무(Lindera obtusiloba BL.) 잎차의 성분변화. 한국식품저장유통학회 지, 10: 488-492, 2003.

황경아, 신승렬, 김광수. 제조방법에 따른 생강나무(Lindera obtusiloba BL.) 잎차의 향기 성분의 변화. 한국식품저장유통학회 지, 12: 68-74, 2005.

황은영, 김동희, 황주영, 김희정, 박태순, 이인선, 손준호. 홍화자, 향부자, 형개 추출물의 미백효과에 관한 연구. 한국식품과 학회지, 44: 76-81, 2012a.

황주영, 박태순, 김동희, 황은영, 이정노, 이지영, 이강태, 이건국, 손준호. 우방자에서 분리한 주름개선 화합물. 생명과학회 지, 22: 1092-1098, 2012b.

황주영, 박태순, 손준호. 감꼭지 추출물과 분획물의 미백효과. 생명과학회지, 23: 383-388, 2013. 


\section{中文摘要}

\section{生姜树花提取物作为天然化妆品原料的应用可行性}

柳賢我，金春得 ${ }^{*}$

南部大学香匠美容学科, 光州, 韩国

目的：探讨生姜树花的药理活性效能，鉴定其作为天然化妆品原料的应用可行性。方法: 利用热水和 $70 \%$ 乙醇分别提取生 姜树花提取物，并对其提取物分别测定抗氧化、美白、抗皱、抗菌活性效果。结果: $500 \mu \mathrm{g} / \mathrm{mL}$ 生姜树花乙醇提取物的 2,2-diphenyl-1-picrylhydrazyl (DPPH)自由基消除能力为 $81.33 \%$, 多酚和类黄酮含量分别为 $152.00,145.27 \mu \mathrm{g} / \mathrm{mL}$, 分 别均高于热水提取物。生姜树花的美白效果显示: $500 \mu \mathrm{g} / \mathrm{mL}$ 生姜树花乙醇提取物与对照群相比抑制了 $31.00 \%$ 酪氨酸酶活 性; 在 B16F10 melanoma细胞中，其提取物对酪氨酸酶以及黑色素合成方面抑制效果也非常优秀，并对 a-melanocytestimulating hormone ( $\alpha-M S H)$ 诱导的酪氨酸酶以及黑色素合成的抑制效果也均高于阳性对照群熊果苷。为确认生姜树 花的抗波效果测定了胶原合成量, 其结果显示: $200 \mu \mathrm{g} / \mathrm{mL}$ 醇提取物与对照群相比胶原合成量为 $130.00 \%$ 。生姜树花提 取物对 Staphylococcus epidermidis (S. epidermidis)、Staphylococcus aureus (S. aureus)、Propionibacterium acnes (P. acnes)等菌的抗菌活性测定结果显示: 乙醇提取物对S. epidermidis、P. acnes菌的抗菌效果优秀。结论: 生姜树花提取物 具有美白、抗怶、抗菌效果，作为天然功能性化妆品原料充分具有可行性。

关键词: 生姜树，抗氧化，美白，抗菌，化妆品 